\title{
Investigating urban space: Potential urban green space in dense city of Yogyakarta
}

\author{
Dyah Widiyastuti ${ }^{1 *}$, Bagus Mudiantoro ${ }^{2}$, and Lilik Andriyani ${ }^{3}$ \\ ${ }^{1}$ Department of Geographic Development, Faculty of Geography, Universitas Gadjah Mada, Indonesia \\ ${ }^{2}$ Centre for Business and Climate Change, University of Edinburgh Business School, Edinburgh \\ ${ }^{3}$ Indonesia Infrastructure Research Centre, Jakarta, Indonesia
}

\begin{abstract}
Urban green space (UGS) is essential for the city to ensure sustainability. The provision of adequate USG, however, is challenging over time, particularly at the city centre area. This study aims to offer a possible framework to identify UGS and assess the potential share from the vacant land into green space using descriptive analysis of remote sensing and secondary data. A case study is applied to assess the UGS and potential area in Yogyakarta City. The result shows that the built-up area in Yogyakarta City is covered around $85 \%$ of the total while the UGS remains halved within less than a decade. In addition, the field visit shows a potential UGS on 16.00 ha from the private vacant land. The application of the framework provides a tool for the city council in maintaining and monitoring the land cover, including identifying the UGS throughout the city. Imposing the regulation on vacant land might encourage the private sector involvement and offers less effort to the city council in providing UGS.
\end{abstract}

\section{Introduction}

Many cities in the world are facing rapid growth of population and development. Urbanisation is a major global concern in the world, where $55 \%$ of the population in 2018 live in cities and it is expected to increase to $68 \%$ by 2050 . The world's urban population has grown rapidly from 751 million in 1950 to 4,2 billion in 2018 while the cities only make up 3\% of the World's surface [21]. Urban areas always are population magnets where jobs opportunities and amenities are concentrated. For those reasons, urban areas, especially in Indonesia, are highly populated [4].

Increasing population will lead to high pressure on urban land utilization. The problems in urban areas becoming complex because they try to accommodate the massive needs for housing and urban infrastructures such as amenities and commercial building [7]. At the same time, green open spaces are considered as the most vulnerable area due to land-use change [15; 22]. Urban development within a short period of time can change the landscape along with substantial destruction to the environment [10]. As the result, environmental issues like an increasing area of urban heat islands, decreasing air and water resources, and rising noise and air pollution, and declining biodiversity become inevitable $[5 ; 11 ; 17]$.

There have been numerous urban studies done to explore the impacts of urbanization towards the green open spaces and how we can further improve it in order to rise our living conditions. Green open spaces have an important role in sustainable development goals. In terms of its function, green open spaces have four main functions which are ecology, social and culture, economic, and aesthetic. They provide ecosystem services, include pollution mitigation because they become an urban lung, microclimate regulation because the trees are lowering the temperature and provides shade effect, rainwater absorber and flood prevention, as well as become urban wildlife habitat $[8 ; 9 ; 12]$. In social and culture sector, green open spaces provide a range of benefits to the inhabitants because they become a place for gathering, relaxing, playing sports and physical activities, give a mental restoration because they provide sense of calmness far from the busy concrete environment $[6 ; 14 ; 19]$. The United Nations Sustainable Development Conference $($ Rio +20$)$ in Rio de Janeiro, Brazil stated that city must have at least 30\% of green open space because green open spaces bring a lot of benefits for the urban populations. This proportion is a minimum measure to guarantee the balance of the ecosystem and improve the aesthetics of the city.

Urban development and activity sometimes produce waste products in the form of urban vacant land [13]. The term of vacant land is broad and diverse, but it is usually pictured as under-utilized lands including bare soil, derelict land, abandon buildings and structures, brownfields, green fields, uncultivated land or marginal agricultural land and recently razed land [2]. As long as urban vacant is abandoned, the benefits are limited, but it has big opportunities to redesign and increasing the ecological and social value when it becomes a green open space.

\footnotetext{
*Corresponding author: dwidiyastuti@ugm.ac.id
} 
This study aims to identify the availability of green open space with a remote sensing image and assess the potential of urban green space improvement with a case study in Yogyakarta City. In this paper, we applied random sampling from the remote sensing, validation using secondary data, and field observation and confirmation to identify the UGS and the potential UGS from the vacant land. This adding the discussion on the random sampling method to assess the UGS [23].

In spatial context, in 1990 Yogyakarta could be categorized as compact city with the core in some subdistricts, namely Danurejan, Gedongtengen, and Gondomanan. The built-up area occupied only $23,19 \%$ while the non-built up area around 76,81\% [18]. In 1995 was the important period that the urbanized area started to increase significantly showed by more built-up area recorded at $33,51 \%$. That trend of urbanized area still continues until 2017, where the built-up area occupied $62,19 \%$ while the non-built-up area continues to decrease at the level of $37,81 \%$. The increasing built-up area might be the pressure of non-built-up area included green open space. Therefore, a well-planned city is needed towards balancing grey area and green area.

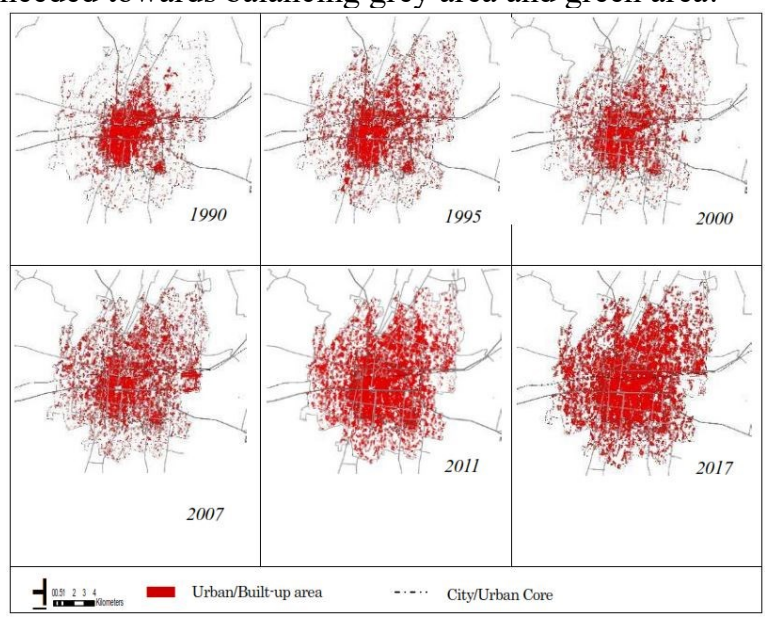

Fig. 1. Yogyakarta urban form transformation in 1990-2017. Source: Rozano and Yan, 2017

\section{Methods}

We develop a framework to assess the UGS by comparing the remote sensing imagery with the historical spatial information. The remote imagery is processed to identify and category the land cover. We distinct between the green land cover with the non-green land cover. The overall green land cover interpreted for calculating the overall UGS. The results of digitization are used to calculate the proportion of green open space calculated with the formula from Ministry of Public Works and Housing [13].

$$
\frac{\text { Overall green open space area }}{\text { Total area of the city }} \times 100 \%
$$

The historical spatial information is gathered from official information about the land cover. Data identification and cleaning are conducted to calculate the total composition of UGS for specific administrative area/region. In our study, we consider the sub-district as the administrative area/region. Further, the historical spatial information provide calibration from the previous step, particularly the confirmation of the land cover.

The field survey is conducted to confirm the condition at the field and verify whether the land plot is public or private land. Random sampling for the verification is applied, while the secondary data supports the field survey with the basic information about the land cover. The definition of private and public are considering the access to the premises. If it is accessible for anybody, the premises are identified as public, otherwise it will be as private. Further, we identify public and private ownership of every area/premises based on qualitative information about the premises from the field survey.

\subsection{Secondary data collection}

Secondary data collection focused on the historical spatial information. The main source of the secondary data is taken from basic data of UGS development plan for Yogyakarta City in 2008, spatial development plans, and basic statistic data. We explore the basic map of UGS development plan as the based map for baseline of the study.

\subsection{Spatial data collection}

Quickbird image of 2015 is used as the remote sensing data. It is interpreted and processed with on-screen digitized. The results are utilised to calculate the proportion of UGS.

The digitization to identify the green space and nongreen space for every sub-district into polygons for each premise. The digitation processes consider the type of the UGS. The classification of UGS is divided into area and corridor [1]. Additionally, the digitised UGS premises are classified into 4 types, i.e. i) corridor, ii) area I - the area with less than $250 \mathrm{~m}^{2}$, iii) area II - with area of 250-24.000 $\mathrm{m}^{2}$; and iv) area III - with area of the land is more than $24.000 \mathrm{~m}^{2}$. The classification and premises use to identify the detailed types of UGS. The types of UGS, then, incorporated the information on public or private space. The processed data, then, verified and confirmed by the field observation.

\subsection{Field Observation}

In this study, image interpretation and field observations will complement each other in order to achieve a minimum standard of interpretation accuracy. Field observations were carried out by random sampling. The distribution of sampling is overall sub-district as the total population and consider $30 \%$ of area for each subdistrict as random sampling to confirm and verify the result of remote sensing. The sampling also took into account the classification of UGS (corridor, area I, area II, area III). The calculation of the accuracy test for research has to meet a minimum of $84 \%$ [20].

Overall Accuracy $=\frac{\text { Correct interpretation sample }}{\text { Total sample }} \times 100 \%$

*Selected sample was $30 \%$ of overall area of green open space 


\section{Results and discussions}

The result finds the accuracy of the remote sensing interpretation of $88.85 \%$, which is acceptable. The result of image digitation shows that Yogyakarta in 2015 only had $18.51 \%$ (less than $30 \%$ of the minimum requirements), with the area of urban green space only 601.64 ha alongside with the growth of the city (Table 1). To fulfil the minimum requirement of urban green space, Yogyakarta must have additional 373.36 ha $(11.49 \%)$. In 2008 the total of urban green space in this city was $1,028.79$ ha or $31.65 \%$ of the total area of the city. It means the city lost 427,15 ha within 7 years.

Table 1. Area Transformation of Green Open Space in 2008 and 2015 .

\begin{tabular}{|l|r|r|r|r|}
\hline Sub-district & \multicolumn{1}{c|}{$\begin{array}{c}\text { The } \\
\text { Needs* } \\
\text { (ha) }\end{array}$} & $\begin{array}{c}\text { UGS in } \\
\mathbf{2 0 0 8} \\
\text { (ha) }\end{array}$ & $\begin{array}{c}\text { UGS } \\
\text { in } \\
\mathbf{2 0 1 5} \\
\text { (ha) }\end{array}$ & $\begin{array}{c}\text { Changing } \\
\text { (\%) }\end{array}$ \\
\hline Danurejan & 33.0 & 20.7 & 11.7 & -43 \\
\hline Gedongtengen & 28.8 & 21.7 & 8.8 & -59 \\
\hline Gondokusuman & 119.7 & 129.5 & 65.7 & -49 \\
\hline Gondomanan & 33.6 & 26.9 & 20.6 & -23 \\
\hline Jetis & 51.0 & 30.3 & 21.4 & -29 \\
\hline Kotagede & 92.1 & 118.0 & 61.9 & -48 \\
\hline Kraton & 42.0 & 24.1 & 18.5 & -23 \\
\hline Mantrijeron & 78.3 & 100.6 & 45.9 & -54 \\
\hline Mergangsan & 69.3 & 52.3 & 32.2 & -38 \\
\hline Ngampilan & 24.6 & 10.5 & 8.1 & -23 \\
\hline Pakualaman & 18.9 & 10.3 & 7.1 & -31 \\
\hline Tegalrejo & 87.3 & 102.3 & 64.2 & -37 \\
\hline Umbulharjo & 243.6 & 324.9 & 207.1 & -36 \\
\hline Wirobrajan & 52.8 & 56.7 & 28.5 & -50 \\
\hline Total Area & 975.0 & $1,028.8$ & 601.6 & -42 \\
\hline Source: ${ }^{*}$ Yogya & & & \\
\hline
\end{tabular}

Source: * Yogyakarta Planning Agency (2008);

${ }^{* *}$ Research Analysis (2017)

\subsection{The availability of green open space}

Table 1. shows changes in the area of urban green space for each district. The most drastically changed of land cover occurred in Gedongtengen with 59\% urban green space changed from 2008-2015. Moreover, Umbulharjo had the widest decrease of urban green space around 117,90 ha from 324,96 ha in 2008 to 207,06 ha in 2015 .

Since 2008, the provision of urban green space in the Danurejan, Gedongtengen, Gondomanan, Jetis, Kraton, Mergangsan, Nggangan and Pakualaman sub-districts has not been able to meet the minimum area requirements of green open space. In particular, the availability of urban green space in the districts of Ngampil, Pakualaman, Danurejan, and Gedongtengen is very limited. The four districts have a very high population density, reaching 191 inhabitants / ha to 244 inhabitants / ha in 2008. Population density decreased in
2015 to reach 148 inhabitants / ha to 205 inhabitants / ha, but the availability of urban green space remains the smallest and tend to decrease.

The availability of urban green space in Gondokusuman, Kotagede, Mantrijeron, Tegalrejo, Umbulharjo and Wirobrajan Districts had exceeded the minimum urban green space area requirement in 2008. The largest proportion of urban green space was in Umbulharjo, Gondokusuman, and Kotagede Districts with a population density of 94 inhabitants / ha to 137 inhabitants / ha. However, the area of urban green space in the three sub-districts experienced a decline in 2015 to the point where it was unable to meet the minimum area requirements of urban green space.

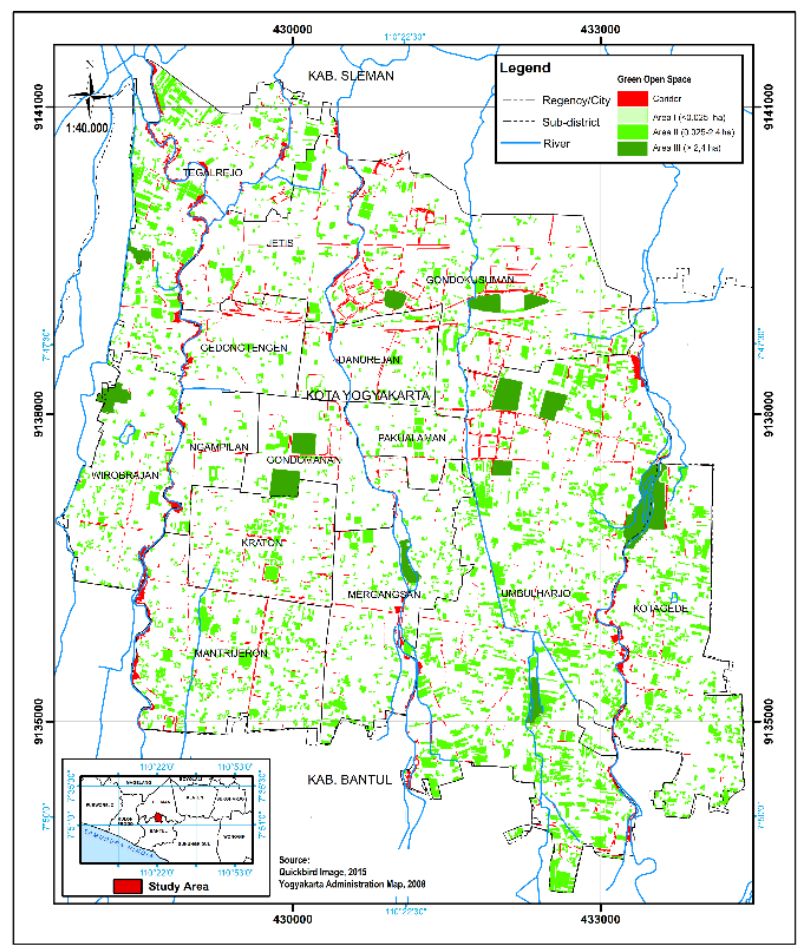

Fig. 2. Green Open Space Availability in Yogyakarta City. Source: Image Digitized, 2017

Fig. 2 shows the distribution of urban green space in Yogyakarta City. It depicts that the availability of urban green space in the city centre is less than the sub-districts in the suburbs. In terms of the spatial plan (Rencana Tata Ruang Wilayah/RTRW), the city centre area including Danurejan, Gedongtengen, and Gondokusuman subdistrict is designated as the centre of urban services which accommodating activities in a regional and international scale, government activities, public and social facilities especially for culture and tourism sector. Those functions can be an attractiveness for people because they can get the optimum services in those subdistricts. Consequently, those three sub-districts severely lost the UGS in the last decade (lost about 51\% of the UGS from 2008.

Pakualaman and Ngampilan which are located in the south of Danurejan and Gedongtengen are designated as the buffer zone for Danurejan and Gedongtengen. Therefore, those four sub-districts be the right destination for people to live and do many activities in the downtown area. Since 2008 until 2015, the proportion of urban green space in these two sub- 
districts is the smallest, while the population density is the highest. To fulfil the basic needs, the land conversion is the most common thing to resolve high demand of housing and settlements or other physical expansion of built-up area, especially on unproductive land which low economic value to become more productive or has a higher economic value. Therefore, urban green space with high ecological and social value is the common option for land conversion.

In view of the fact that Yogyakarta City is undergoing rapid growth of population density, oversee the development in the suburbs is challenging. Umbulharjo that adjacent with Bantul Regency plays a strategic role as an entrance for the commuter to the city. The spatial plan also stated that Umbulharjo sub-district is a priority area that must be developed compared to other sub-districts which are relatively developed. According to the result revealed in Table 1, we can see that in the last seven years, Umbulharjo has lost 36 percent of urban green space. Having a proper planning policy and regulation is not enough, but ensure the successful implementation and enforcement are important. Unsuccessful enforcement of the development plan might lead to the loss of urban green space as happened to Umbulharjo sub-district.

\subsection{The types of green open space}

Among the two classifications of green open space - area and corridor - the type of area is most often found with various types. There are five types of urban green space in the form of an area, they are house/building yards, agricultural land, parks, cemeteries, and urban forest. The yard and agricultural land have the largest proportion, namely $27.92 \%$ and $21.44 \%$. Utilization of yard and agricultural land is dominated by passive activities, such as sitting, relaxing, socializing, yet on some pages the school buildings are equipped with sports facilities and games to support active activities.

Parks, cemeteries and urban forests have proportions in a sequence of $14.09 \%, 11.92 \%$ and $8.07 \%$. These urban green spaces are accessible for the public, yet to access the urban forest, people have to pay an entrance ticket. Parks and urban forests can support passive and active activities with park bench facilities, pedestrian circulation paths, sports facilities, and children's play equipment, while funerals only support passive activities.

Urban green space which is green corridors is found in the form of road corridors and river corridors. Road corridors with a proportion of $11.13 \%$ are found in the form of pedestrian paths, median roads, and island roads that are associated with collector road or arterial road with road widths ranging from 7 meters upwards. River corridor with a proportion of $5.43 \%$ is part of the river border that has a vegetation cover. In some river segment, there is also a river border which is not covered by vegetation but is built into a settlement. The two types of green corridors are public spaces that can accommodate passive activities.

The results of field observations also find that there is vacant land that is identified as urban green space in the form of an area when image digitization process.
This is caused by the cover of vegetation in the vacant land area. The proportion reaches $16.20 \%$. Vacant land is a part of private space in the form of post-industrial sites, derelict sites, and unattended with vegetation sites associated with settlements or buildings.

Table 2. Observation Result.

\begin{tabular}{|c|c|}
\hline Type of urban green space & Description \\
\hline House/building yard & $\begin{array}{l}\text { - Area } \\
\text { - Private } \\
\text { - Proportion: } 27.92 \% \\
\text { - Associate with house, } \\
\text { office, school } \\
\text { - Dominated by } \\
\text { passive activity, but } \\
\text { schoolyard could be } \\
\text { completed with court } \\
\text { or sport area } \\
\text { - Facility: park bench }\end{array}$ \\
\hline Agricu & $\begin{array}{l}\text { - } \text { Area } \\
\text { - } \text { Private } \\
\text { - } \text { Proportion: } 21.44 \% \\
\text { - Associate with } \\
\text { - } \text { settlement or road } \\
\text { - } \text { Dominated by } \\
\text { passive activity } \\
\text { - As a part of } \\
\text { productive land } \\
\text { - Facility: irrigation } \\
\text { channel }\end{array}$ \\
\hline Park & $\begin{array}{l}\text { - Area } \\
\text { - Public } \\
\text { - Proportion: } 14.09 \% \\
\text { - Associate with } \\
\text { settlement, building, } \\
\text { and road } \\
\text { - Support both passive } \\
\text { and active activities } \\
\text { - Facilities: park } \\
\text { bench, playground } \\
\text { equipment, court, and } \\
\text { pedestrian circulation } \\
\text { line }\end{array}$ \\
\hline & $\begin{array}{l}\text { - } \text { Area } \\
\text { - Public } \\
\text { - Proportion: } 11.92 \% \\
\text { - Associate with paddy } \\
\text { field, river, and } \\
\text { settlement } \\
\text { - Passive activity } \\
\text { - Dominated by } \\
\text { cemented graves that } \\
\text { can reduce the } \\
\text { ecological function as } \\
\text { water catchment } \\
\text { areas }\end{array}$ \\
\hline Hitan & $\begin{array}{l}\text { - Area } \\
\text { - Public } \\
\text { - Proportion: } 8.07 \% \\
\text { - Associate with river, } \\
\text { building, and road } \\
\text { - As a part of } \\
\text { recreation area } \\
\text { - Support both passive } \\
\text { and active activities } \\
\text { - Facilities: park } \\
\text { bench, playground } \\
\end{array}$ \\
\hline
\end{tabular}




\begin{tabular}{|c|c|}
\hline Type of urban green space & Description \\
\hline & $\begin{array}{l}\text { equipment, court, } \\
\text { food court, and } \\
\text { pedestrian circulation } \\
\text { line }\end{array}$ \\
\hline Road corridor & $\begin{array}{l}\text { - } \text { Corridor } \\
\text { - Public } \\
\text { - Proportion: } 11.13 \% \\
\text { - Associate with road } \\
\text { and building } \\
\text { - Passive activity } \\
\text { - In the form of } \\
\text { pedestrian paths, road } \\
\text { medians, and island } \\
\text { paths } \\
\end{array}$ \\
\hline River corridor & $\begin{array}{l}\text { - } \text { Corridor } \\
\text { - } \text { Public } \\
\text { - Proportion: } 5.43 \% \\
\text { - Associate with river } \\
\text { and settlement } \\
\text { - Passive activity }\end{array}$ \\
\hline $\begin{array}{l}\text { Vacant land } \\
\end{array}$ & $\begin{array}{l}\text { - } \text { Area } \\
\text { - Private } \\
\text { - Proportion: } 16.20 \% \\
\text { - Associate with } \\
\text { settlement and } \\
\text { building } \\
\text { - Unutilised land, is } \\
\text { part of post-industrial } \\
\text { sites, derelict sites, } \\
\text { and unattended with } \\
\text { vegetation sites } \\
\end{array}$ \\
\hline
\end{tabular}

Source: Field Observation (2017)

\subsection{Green open space potential area}

Our findings from interpretation results and field observation shows there are 16,00 ha of vacant land that can be converted into UGS. The image interpretation revealed that area is potentially UGS, while the field observation shown otherwise. There are 68 areas scattered throughout several sub-districts in particular at Umbulharjo and Tegalrejo. Vacant lands in Yogyakarta City are identified as private space where the utilization of these spaces depend on the owners. Presumably, these vacant lands can be converted into built up area soon.

Vacant lands are potential to be used as UGS. It can benefit to the social and ecological quality of the city considering the natural elements such as vegetation and soil are retained. Vacant land utilisation might increase the portion of urban green open space from $18,51 \%$ into $19,01 \%$ with a limited effort. On that perspective, the city council might consider administering the conversion of vacant land area as an urban green space.

UN Habitat has stated that UGS plays important roles in urban, thus understanding its dynamics and availability can help urban planning and human wellbeing. The results indicate that high demand of the human settlements and economic activities put significant pressure to the change of the land use that affect to the deficiency of UGS. The private vacant land, however, may offer opportunity to increase the UGS, while greater efforts is needed to impose the private owner to maintain and ensuring the green coverage in their land. The green space requirement is certainly could not be fulfilled by the city government only but collaboration among stakeholders are required to maintain the UGS. Private sector can bring a positive impact on increasing the proportion of green space, by maintaining their vacant land kept green.

Table 3. Amount of Vacant Land in Yogyakarta City.

\begin{tabular}{|l|r|}
\hline \multicolumn{1}{|c|}{ Sub-district } & Area (ha) \\
\hline Danurejan & 0.02 \\
\hline Gedongtengen & Unidentified \\
\hline Gondokusuman & 0.78 \\
\hline Gondomanan & 0.21 \\
\hline Jetis & 2.13 \\
\hline Kotagede & 1.85 \\
\hline Kraton & 0.35 \\
\hline Mantrijeron & 0.89 \\
\hline Mergangsan & 1.08 \\
\hline Ngampilan & 0.76 \\
\hline Pakualaman & 0.50 \\
\hline Tegalrejo & 2.59 \\
\hline Umbulharjo & 4.07 \\
\hline Wirobrajan & 0.77 \\
\hline Total Area & 16.00 \\
\hline Source: Research Analysis (2017)
\end{tabular}

\section{Conclusion}

The UGS in this city remain halved within less than a decade. In 2007, urban green space reached $31.65 \%$ of the total area and met the minimum green open space requirement. On contrary, the UGS decreased significantly in 2015 into $18.51 \%$.

There are a potential of 16 ha UGS in Yogyakarta that can increase availability of green are in the City. It is an opportunity to increase the composition of UGS by ensuring greening in private vacant lands. Our case study shows, it can increase the total area of UGS from $18.51 \%$ into $19.01 \%$ with limited effort.

Various policies and regulations have been issued by the city government, but it has not been able to maintain and increase the proportion of UGS. City council, ideally, must control and maintain the existing green open space. The application of the framework provides a tool for the city council in maintaining and monitoring the land cover of their city including identify the UGS throughout the city. Imposing the regulation on vacant land might encourage the private sector involvement and offers less effort to city council in providing UGS. It is noticed that the further longitudinal study to explore the dynamics of UGS is necessary, the regular and 
periodic data collection might support the application of this framework.

\section{References}

1. G. Austin. Green Infrastructure for Landscape Planning. New York: Routledge. (2014)

2. A. O. M. Bowman, \& M. A. Pagano, Terra incognita: Vacant land and urban strategies. Washington, DC: Georgetown University Press. (2004)

3. Central Bureau of Statistics (BPS). Statistik Daerah Kota Yogyakarta 2018. The Yogyakarta Central Bureau of Statistics. (2018)

4. K. Men Chan \& T. Thuy Vu. A Landscape Ecological Perspective of the Impacts of Urbanization on Urban Green Spaces in the Klang Valley. Appl Geogr., 85, 89 - 100. (2017)

5. Y. Chen, H. Zhou, H. Zhang, G. Du, \& J. Zhou. Urban flood risk warning under rapid urbanization. Environ. Res., 139, 3-10. (2015)

6. A. Chiesura, The role of urban parks for the sustainable city. Landsc Urban Plan., 68, 129-138. (2004)

7. B. Cohen, Urbanization in developing countries: Current trends, future projections, and key challenges for sustainability. Technol. Soc., 28. (2006)

8. F. J. Escobedo, T. Kroeger, \& J. E. Wagner, Urban forests and pollution mitigation: Analysing ecosystem services and disservices. Environ. Pollut, 159, 2078-2087. (2011)

9. S. Gairola \& M. S. Noresah, Emerging trend of urban green space research and the implications for safeguarding biodiversity: A Viewpoint. Nature and Science, 8, 43-49. (2010)

10. N. B. Grimm, S. H. Faeth, N. E. Golubiewski, C. L. Redman, J. Wu, X. Bai, et al. Global change and the ecology of cities. Science. 319. (2008)

11. S. Grimmond, Urbanization and global environmental change: Local effects of urban warming. Geogr J, 173. (2007)

12. C.Y Jim \& W.Y. Chen, Perception and Attitude of Residents Toward Urban Green Spaces in Guangzhou (China). Environ Manage., 38, 338 349. (2006)
13. M. Kim \& G. Kim, Typology of urban left-Over space. In conference abstracts, 2012 CELA annual meeting, March 28-31. (2012)

14. J. Maas, R. A. Verheij, P. P. Groenewegen, S. de Vries, \& P. Spreeuwenberg, Green Space, Urbanity, and Health: How Strong is the relation? J. Epidemiology Community Health, 60, 587-592. (2006)

15. R. I. McDonald. Ecosystem service demand and supply along the urban-to-rural gradient. J. Conserv. Plan. 5, 1-14. (2009).

16. Ministry of Public Works and Housing. Peraturan Menteri Pekerjaan Umum dan Perumahan Rakyat No. 5 Tahun 2008 tentang Pedoman Penyediaan dan Pemanfaatan Ruang Terbuka Hijau di Kawasan Perkotaan. Jakarta. (2008). In Bahasa

17. B. Pradhan, \& S. Lee, Delineation of landslide hazard areas on Penang Island, Malaysia, by using frequency ratio, logistic regression, and artificial neural network models. Environ. Earth Sci., 60. (2010)

18. B. Rozano \& W. Yan. Monitoring the transformation of Yogyakarta's urban form using remote sensing and geographic information system. IOP Conference Series: Earth and Environmental Science. 148. (2017)

19. S. Schetke, S. Qureshi, S. Lautenbach, and N. Kabisch. What determines the use of urban green spaces in highly urbanized areas? - examples from two fast growing Asian Cities. Urban For Urban Green, 16, 150-159. (2016)

20. Sutanto. Penginderaan Jauh Jilid I. Yogyakarta: UGM Press. (1986). In Bahasa

21. United Nations. World Urbanization Prospects: The 2018 Revision. (2018)

22. N. S. G. Williams, M. W. Schwartz, P. A. Vesk, M. A. McCarthy, A. K. Clemants, R. T. Corlett, R. P. Duncan, B. A. Norton, K. Thompson, M. J. McDonnell, A conceptual framework for predicting the effects of urban environments on floras. J. Ecol. 97, 4-9. (2009)

23. E. G. Parmehr, M. Amati, J. Elizabeth, S. J. Livesley Taylor, Estimation of urban tree canopy cover using random point sampling and remote sensing methods. Urban Forestry \& Urban Greening. 20, 160 - 171. (2016) 